Науковий вісник Дьвівського націонадьного університету ветеринарної медицини та біотехнологій імені С.3. Гжицького

\author{
Scientific Messenger of Lviv National University \\ of Veterinary Medicine and Biotechnologies
}

UDC 543. 3: 628. 1

\title{
The investigation of the quality of water resources of decentralized water-supply of rural areas in Berezhany district
}

\author{
N.M. Glovyn, O.V. Pavliv
}

Separated subdivision of National University of Life and Environmental Sciences of Ukraine «Berezhany Agrotechnical Institute», Berezhany, Ukraine

Article info

Received 07.02.2018

Received in revised form 06.03 .2018

Accepted 09.03.2018

Separated subdivision of National University of Life and Environmental Sciences of Ukraine «Berezhany Agrotechnical Institute», Academichna Str., 20, Berezhany, Ternopil region, 47501, Ukraine. Tel.: +38-067-208-60-99 E-mail:nadiaglovin@gmail.com
Glovyn, N.M., \& Pavliv, O.V. (2018). The investigation of the quality of water resources of decentralized water-supply of rural areas in Berezhany district. Scientific Messenger of Lviv National University of Veterinary Medicine and Biotechnologies. 20(84), 109-114. doi: $10.15421 /$ nvlvet 8420

The main anthropogenic factors of chemical and toxicological pollution of decentralized water-supply sources in rural settlements are examined. Complex estimation of water pollution level is made and the dependence of subsoil waters quality from season changes is elicited on the example of countryside within Berezany district Ternopil region. Berezhany district is mostly agricultural and that's why agriculture becomes one of the biggest polluters of water resources especially subsoil. Dangerous source of water pollution, especially in the period of spring flooding and rainfall flooding are diffuse runoffs from agricultural areas/ in three to four times more nutrients and suspended solids are imposed from them than from natural areas. In the qualitative composition (cation and anions content mineralization) among subsoil's waters of Ternopil region, that are used for water-supply, essentially dominate bicarbonate-sulfate calcium-sodium waters with mineralization $0.2-0.8 \mathrm{~g} / \mathrm{dm}^{3}$. Especially in Berezhany district subsoil fresh waters have bicarbonate-sulfate calcium-sodium composition with common mineralization of $0.5-0.7 \mathrm{~g} / \mathrm{dm}^{3}$. There are 3432 artesian wells in the region, including 2679 in the countryside and 753 in towns and 74296 mine pits. It is found that on this territory low concentrations of nitrites during the whole period of research are marked. Except for isolated cases of its growth: in the village Zhukiv (to $0.02 \mathrm{mg} / \mathrm{dm}^{3}$ ) in autumn and Posurhiv (to $0.04 \mathrm{mg} / \mathrm{dm}^{3}$ ) in spring, that are explained by the increasing of quantity of fall-outs and respectively, growth of runoff from agricultural lands. Small concentrations of nitrites in groundwater's on the district territory (less more than $0.01 \mathrm{mg} / \mathrm{dm}^{3}$ ) are due to their extreme instability. They are oxidized, moving to the most stable inorganic nitrogen - nitrates. Concerning nitrates, their high levels with gradual growth from spring to autumn is found. In the village Zhukiv the figure does not exceed the norm, except in autumn, where it is $52.35 \mathrm{mg} / \mathrm{dm}^{3}$. Significant increase of nitrates concentration on the territory of these villages in autumns is explained by the fact, than during the rains polluting substances penetrated into groundwater's, that drained from fields, where nitrogen fertilizers were given. In summer this increase can be explained by fertilization. Receiver results speak about poor state of ground waters as the sources of decentralized water-supply due to increasing of nitrate contents in these objects. It is shown that effluents and fertilizers that are given into the soil, make the most influence on the quality of water from underground sources. It is also founded the increasing of contents of nitrites, nitrates, chlorides, sulphates in spring during snowmelting and in autumn during rains. Considering the excess of nitrates norm in ground water it is necessarily control making of nitrogen fertilizers into soil. It is necessary to conduct purification of drinking water before its usage. It is obviously that on the areas with higher percentage of "unstandard" water the morbidity of cancer is higher. The effect of influence of water with higher contents of nitrates increases against the background of malnutrition that is particularly in the current crisis period of life.

Key words: subsoil waters, well, chemical pollution index, toxicology pollution index, water hardness.

\section{Дослідження якості водних ресурсів децентралізованого водопостачання сільських місцевостей у межах Бережанського району}

\author{
Н.М. Гловин, О.В. Павлів
}


Відокремлений підрозділ Національного університету біоресурсів і природокористування Украӥни «Бережанський агротехнічний інститут», м. Бережани, Украӥна

Розглянуто основні антропогенні чинники хімічного і токсикологічного забруднення джерел децентралізованого водопостачання у сільських населених пунктах. Проведено комплексну оцінку рівня забрудненості води і виявлено залежність якості підземних вод від сезонних змін на прикладі сільських місиевостей у межах Бережанського району Тернопільської області. Бережанський район переважно аграрний, а тому сільське господарство стало одним з найбільших забруднювачів водних ресурсів, зокрема підземних. Небезпечним джерелом забруднення природних вод, особливо в періоди весняної повені $i$ зливових паводків, $\epsilon$ дифузні стоки з сільськогосподарських угідь. 3 них виноситься в середньому в 3-4 рази більше біогенних $і$ завислих речовин, ніж з природних угідь. За якісним складом (вміст катіонів і аніонів, мінералізачія) у Бережанському районі підземні прісні води мають гідрокарбонатно-сульфатний кальчієво-натрієвий склад при загальній мінералізації 0,5-0,7 г/дм. В області нараховується 3432 артезіанські свердловини, у т. ч. у сільській місиевості - 2679 та 753 - у містах і селищах міського типу та 74296 шахтних колодязів. Встановлено, щзо на даній території дослідження відмічаються низькі концентрачї нітритів протягом усього періоду дослідження. Вони окислюються, переходячи в найбільш стійкі неорганічні сполуки азоту - нітрати. Що стосується нітратів, то встановлено їх високі показники із поступовим зростанням від весни до осені. Значні підвищення концентрації нітратів на території досліджуваних сіл восени пояснюються тим, щчо під час дощів у трунтові води потрапляли забруднювальні речовини, щцо стікали з полів, на які вносили азотні добрива. Влітку підвищення можна пояснити внесенням добрив. Отримані результати говорять про незадовільний стан трунтових вод, як джерел децентралізованого водопостачання, саме за рахунок збільшення вмісту нітратів у даних об'єктів. Також встановлено зростання вмісту нітритів, нітратів, хлоридів, сульфатів навесні під час танення снісів та восени під час дощуів. $\partial u$.

Ключові слова: трунтова вода, криниця, хімічний показник забруднення, токсикологічний показник забруднення, твердість во-

Природня вода - це особливий коктейль природних мікроелементів, в яких формується і завдяки яким функціонує організм людини. По суті, вода найбільш важлива рідина в природі. У воді зародилося життя. Життя є лише там, де $\epsilon$ вода. В організмі людини клітини можуть функціонувати лише у водному середовищі. Це стосується синтезу білків, ферментативних реакцій та інших обмінних процесів. Найбільш близька до такої води є джерельна. 3 якою насолодою людина під час спраги припадає до животворної вологи джерела. Якою смачною та корисною $\epsilon$ природня артезіанська вода.

Справжня природна питна вода - це вода, яка створена природою, має в своєму складі всі необхідні мікро- i макроелементи в оптимальному, самоорганізованому стані, завдяки чому така вода має власну біоенергетику, є живою системою та максимально відповідає за основними характеристиками воді організму людини

Проте внаслідок активної господарської діяльності людини на Планеті різко знижується якість питної води. Вода, яка отримана із природних джерел або пробурених свердловин, без зовнішнього впливу на хімічні і фізичні властивості природної мінеральної води - є великим дефіцитом у нашому сьогоденному житті.

В основному переважна частина сільського населення споживають воду з колодязів та індивідуальних свердловин, які у переважній більшості перебувають у незадовільному технічному стані, питна вода використовується без попереднього очищення та знезараження, не відповідає санітарним нормам благоустрій прилеглої території до криниць, відсутність стоку і можливість підтоку дощових вод.

Актуальність дослідження. За даними Спільної моніторингової програми ВООЗ/ЮНІСЕФ, доступом до централізованого водопостачання користувалося лише $22 \%$ сільських мешканців. Решта сільських жителів використовують інші джерела - струмки, криниці, неглибокі свердловини. Особливо гострою ця проблема $\epsilon$ в Бережанському районі, оскільки ос- новним джерелом водопостачання і надалі залишаються криниці та поверхневі води.

У сільській місцевості поширено використання децентралізованих джерел водопостачання (колодязів та індивідуальних свердловин). Всі вони мають нормативну зону санітарної охорони, це одна з основних санітарних вимог, яка запобігає токсикологічному та хімічному забрудненню води в них. Що стосується розміщення колодязів на території приватного домоволодіння, то, враховуючи невелику площу земельних ділянок, на них неможливо створити необхідну зону їх санітарної охорони. I тому поряд з джерелом водопостачання часто містяться і господарські споруди для тварин, і туалети з вигребами, і гнойові купи, які $€$ джерелами нітратів, що призводять до забруднення ними грунту і відповідно грунтової води в ній (Hordejnk, 1996). Найбільш розповсюдженим є забруднення підземних вод сульфатами, хлоридами, сполуками азоту (нітрати, аміак, амоніт), нафтопродуктами, фенолами, сполуками заліза, важкими металами, що робить їх непридатними для використовування у питних цілях (Zapolskyi, 2005). Детальніше у наших дослідженнях ми зупинилися на вивченні проблеми в Україні глобального забруднення грунтових вод неорганічними сполуками нітрогену, серед яких в основному переважають нітрати. До грунтових вод нітрати потрапляють через грунт, основними джерелами забруднення якого $\epsilon$ мінеральні добрива, рідкі стоки 3 тваринницьких комплексів, природні опади, а також органічні відходи (Zenin and Belousova, 1988; Zakon Ukrainy, 2002; Derzhavni sanitarni normy ta pravyla, 2010). Варто відмітити, що нітратний азот найбільш рухома форма азотних сполук у грунті: вони легко вимиваються необхідним потоком води аж до рівня грунтових вод, де відбувається постійне їх нагромадження, а в результаті - нітратне забруднення. При цьому в грунті їх вміст незначний (Zapolskyi, 2005).

Бережанський район переважно аграрний, а тому сільське господарство стало одним 3 найбільших забруднювачів водних ресурсів, зокрема підземних. Небезпечним джерелом забруднення природних вод, 
особливо в періоди весняної повені і зливових паводків, є дифузні стоки з сільськогосподарських угідь. 3 них виноситься в середньому в 3-4 рази більше біогенних і завислих речовин, ніж 3 природних угідь (Michalczyk, 1996; Himicheskij i bakteriologicheskij analiz, 2004). Отже, якщо врахувати стан забруднення підземних джерел, то питання задоволення потреб сільського населення у питній воді високої якості є надзвичайно гострою проблемою.

Одним з найпоширеніших видів забруднень такої води є забруднення сполуками нітрогену, насамперед нітратами і нітритами. Значна їх концентрація у воді може бути досить небезпечною для людини (Linnik, 1999). Динаміка складу, співвідношення концентрацій мінеральних і органічних форм нітрогену вказує на напрямок домінуючих процесів самоочищення водойм.

Метою досліджень було проведення моніторингових спостережень за якістю колодязної води (шахтних колодязів, криниць, індивідуальних свердловин), що пропонується мешканцям в сільських населених пунктах Бережанського району Тернопільської області за комплексом органолептичних, фізико-хімічних (гравіметричний, титриметричний, колориметричний і спектрофотометричний), хімічних показників.

\section{Матеріал та методи досліджень}

Матеріалом для проведення досліджень були середні зразки децентралізованих джерел водопостачання за хімічними показниками, а саме підгрунтові води (криниці), шахтні колодязі, індивідуальні свердловини на територіях, що підлягають техногенному впливу у сільських місцевостях. Відбір, зберігання та транспортування проб води проводили згідно з ГОСТом 17.1.5.05-85, $\mathrm{pH}$ води визначали потенціометрично, вміст нітрат-іонів - згідно з ГОСТом 18826-73, органолептичні показники - згідно з ГОСТом 335174, хлориди - згідно з ГОСТом 4245-72, нітрити згідно з ДСТУ ISO 6777-2003, аміак - згідно з ДСТУ ISO 6778-2003. Проаналізовано такі показники: pH, вміст хлоридів, сульфатів, нітратів, нітритів, азоту амонійного та загальну твердість води. Зразки води відбирали сезонно (зима, весна, літо, осінь) у різних точках регіону дослідження (Zapolskyi, 2005). Вміст хлоридів визначали титриметричним методом, який базується на осадженні хлорид-іонів розчином нітрату аргентуму $\mathrm{AgNO}_{3}$ за присутності дихромату калію $\mathrm{K}_{2} \mathrm{CrO}_{4}$ як індикатора (Himicheskij i bakteriologicheskij analiz, 2004). Під час титрування $\mathrm{AgNO}_{3}$ спочатку утворюється осад $\mathrm{AgCl}$ білого кольору. Коли всі хлорид-іони осаджені, при подальшому додаванні утворюється цегляно-червоний осад хромату аргентуму $\mathrm{Ag}_{2} \mathrm{CrO}_{4}$. Якщо вміст хромат іонів не перевищує $100 \mathrm{мг} /$ дм $^{3}$, для титрування використовували розчин нітрату аргентуму 3 концентрацією 0,01 моль/дм ${ }^{3}$ Визначення загальної твердості води проводилося на

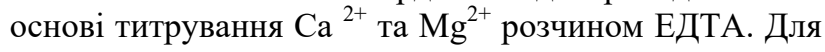
фіксування точки еквівалентності використовували барвник еріохром чорний Т. При $\mathrm{pH}=7-11$ органічний барвник, що відноситься до класу металохромних індикаторів, утворював 3 катіонами забарвлені ком- плексні сполуки. Вміст сульфат-іонів визначали фотометричним методом з використанням розчину хлориду барію в суміші гліколю і етилового спирту. До 5 мл досліджуваної води додавали 1-2 краплі хлоридної кислоти (1:1), 5 мл стандартного розчину і ретельно змішували. Через 30 хв вимірювали оптичну густину при довжині хвилі 300 нм в кюветі 2 см. Вміст сульфат-іонів визначають за градуювальним графіком (Hordejnk, 1996). Вміст нітратів визначали колориметрично 3 фенолдисульфокислотою за утворенням нітровмісного фенолу жовтого кольору (Linnik, 1999; Himicheskij i bakteriologicheskij analiz, 2004). Визначення нітритів засноване на здатності нітритів діазотувати сульфатну кислоту (реактив Грісса) 3 утворенням діазосполуки 3 1-нафтиламіном червонофіолетового кольору. Вміст амонію визначали фотометричним методом за якісною реакцією з реактивом Несслера, $\mathrm{pH}$ води визначали за допомогою іономіра. Одержані дані піддавали статистичній обробці.

\section{Результати та їх обговорення}

В 16 населених пунктах району проводився водозабір зі свердловин, зокрема: селах Баранівка, Біще, Жуків, Комарівка, Куропатники, Літятин, Потутори, Посухів, Шибалин. В 33 населених пунктах забір питної води проводиться із природніх джерел. Відсутні системи централізованого питного водопостачання в 5 населених пунктах, а саме: селах Баранівка, Біще, Посухів, Рибники та Саранчуки.

Органолептичні показники. Аналіз зовнішнього вигляду, кольоровості, смаку та присмаку, запаху, мутності (Derzhavni sanitarni normy ta pravyla, 2010) показав, що якість води, відібраної з населених пунктів району (Баранівка, Біще, Посухів, Рибники та Саранчуки) із нецентралізованих джерел, відповідає встановленим нормам і має достатньо високу якість.

Фізико-хімічні показники. Найбільш агресивною (стосовно хімічних і біологічних процесів, стійкості до різних форм міграції елементів, агресивності відповідно до металів тощо) $є$ вода зі свердловин (показник $\mathrm{pH}=7)$. Менш агресивною за показником $\mathrm{pH} \epsilon$ джерельна вода та вода із шахтних колодязів. Найнижчі показники $\mathrm{pH}$ у зразках води «Біще» та джерела у районі Сторожисько (6,1 та 6,9 відповідно). За якісним складом (вміст катіонів і аніонів, мінералізація) серед підземних вод Тернопільської області, які використовуються для нецентралізованого водопостачання, суттєво переважають гідрокарбонатно-сульфатні кальцієво-натрієві води з мінералізацією 0,2-0,8 г/дм³. I, зокрема, у Бережанському районі підземні прісні води мають гідрокарбонатно-сульфатний кальцієвонатрієвий склад при загальній мінералізації 0,50,7 г/дм ${ }^{3}$.

Жорсткість води, як відомо, визначається присутністю у ній розчинених солей кальцію та магнію. Нами були визначені окремий вміст кожної із солей i, звичайно, загальна жорсткість для всіх відібраних зразків води. Аналіз показав, що вода в усіх відібраних зразках середньої жорсткості, згідно з А.А. Зениним (Zenin and Belousova, 1988). Джерельна вода «Баранівка» (5 ммоль/дм $\left.{ }^{3}\right)$, шахтна вода «Посухів» 
(4 ммоль/дм³ ) характеризуються як м'які води. Для усіх зразків води жорсткість кальцієва. Тому процес кип'ятіння та утворення двооксиду вуглецю допоможуть знизити жорсткість води (але за показниками жорсткість перебуває в межах норми). Характеристика вмісту сульфатів, хлоридів не показала перевищень ГДК. Вміст хлоридів у досліджуваній воді не перевищує 90 мг/дм ${ }^{3}$ (ГДК 350 мг/дм³ ). Встановлена значна різниця між вмістом сульфатів: у воді, що постачається 3 свердловин, вміст сульфатів складає 88,5 мг/дм³, у воді, що подається із шахтних колодязів, складає 152,4 мг/дм ${ }^{3}$. Аналіз показав низький вміст сульфатів у воді 3 свердловин. Найвища кількість сульфатів міститься у воді «Біще» - 121,0 мг/дм³ ${ }^{3}$ найнижчий вміст сульфатів - у воді «Баранівка» - 36,1 мг/дм ${ }^{3}$. Серед джерельних вод найвищий показник вмісту сульфатів є в джерельній воді «Сторожисько» (112,3 мг/дм $\left.{ }^{3}\right)$. Аналіз на вміст хлоридів показав, що у зразках джерельної та води зі свердловин його вміст незначний, далекий до значень ГДК, і перебуває в межах від 30 до 90 мг/дм³.

Токсикологічні показники. Проводився аналіз на вміст водорозчинних форм таких металів у воді: марганець, кадмій, нікель, кобальт, хром (III), цинк, свинець, мідь, алюміній, залізо. Результат був очікуваний. Вміст жодного із металів не перевищує ГДК згідно 3 нормативними документами (Derzhavni sanitarni normy ta pravyla, 2010) і відрізняються за вмістом між собою несуттєво. Проте виявилась особливість: життєво важливі елементи містилися у воді в надто низьких концентраціях. Це своєю чергою стосується марганцю, міді й особливо цинку. Не слід недооцінювати вміст металів у воді. Небезпечне перевищення вмісту елементів, як і надто низький рівень, також призводить до негативних наслідків. Марганець допомагає утилізувати двооксид вуглецю у воді (жорсткість), бере участь у процесах відновлення нітратів; цинк і мідь належать до достатньо активних мікроелементів, які впливають на ріст, нормальний розвиток і функціонування організму людини. Наприклад, при нормі у 1 мг/дм³ найвищий вміст цинку 0,16 мг/дм ${ }^{3}$ у воді, яка постачається з свердловин, а середній вміст цинку у воді складає 0,06-0,08 мг/дм ${ }^{3}$, що є надто низьким.

Досліджувався вміст нітратів, нітритів, аміаку.

Найбільш забруднені нітратами води шахтних колодязів, що мають невелику глибину залягання 1,56 м та здійснюють забір води 3 поверхневих водоносних горизонтів. Першими від поверхні землі залягають грунтові води, що приурочені до четвертинних відкладів, які покривають майже всю територію району. Вони характеризуються змінним рівневим режимом та більш-менш постійним фізико-хімічним складом. Глибина залягання грунтових вод становить від 0 до 20 м, для господарсько-питних потреб ці води каптуються через шахтні колодязі та індивідуальні свердловини. У зв'язку з господарською діяльністю цей водоносний горизонт часто забруднений залишками мінеральних добрив, пестицидів, а також нафтопродуктами і солями важких металів. Про наявність високого нітратного фону у грунтових водах свідчить також забруднення органічними сполуками, які пройшли ланцюг біохімічних перетворень від амонійної до нітратної форм. Трансформацію сполук нітрогену у водному середовищі можна подати так:

- наявність іонів амонію в грунтових водах - результат діяльності мікроорганізмів. У деяких випадках іони амонію можуть утворюватися внаслідок анаеробного відновлення нітритів та нітратів. Підвищений вміст іонів амонію свідчить про погіршення санітарного стану води. Зростання вмісту зумовлене надходженням у грунтові води господарсько-побутових стічних вод, азотних і органічних добрив. Високий вміст амонійного нітрогену у воді криниць часто супроводжується присутністю й інших небажаних речовин, наприклад марганцю, заліза, сірководню тощо;

- нітрити як продукт біохімічного окиснення амонію $є$ сполуками нестійкими і виявляються лише при порівняно свіжому забрудненні джерела (Pennington, and Chavez, 2000; Mackey et al., 2014). Бактерії роду Nitrosomonas окислюють іони амонію до $\mathrm{NO}_{2}^{-}$, а бак-

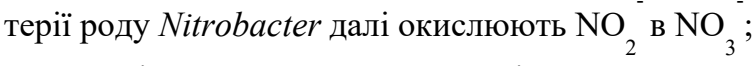

- третім компонентом в системі взаємоперетворень сполук нітрогену є нітрати, що роблять воду небезпечною, зокрема для дітей, тому що при перевищенні вмісту у воді вище за санітарну норму призводять до тяжких захворювань, зокрема, до водно-нітратної метгемоглобінемії, яка може призвести до летального наслідку. Наявність нітратів у воді пов'язана із процесами нітрифікації амонійних іонів в присутності кисню, атмосферними опадами, стічними водами та змивом із сільськогосподарських угідь (Obukhov, 1988; Rozkowski, 1996).

Нітрати є проміжним продуктом розкладання органічних речовин (Huang et al., 2012). Ланцюг біохімічних перетворень «амоніфікація - нітрифікація денітрифікація» може бути призупинений на певній стадії, це залежить від зовнішніх умов. Розкладання органіки в аеробних умовах збагачує розчини нітратами $\left(\mathrm{NO}^{3}\right)$ та нітритами $\left(\mathrm{NO}^{2-}\right)$, які інтенсивно поглинаються рослинами (Obukhov, 1988). Проникнувши 3 потоками води глибше за кореневий шар, ці сполуки не затримуються вбирним комплексом грунту, а потрапляють у грунтові води і мігрують із їх потоком. Саме такий механізм прийнято вважати найвірогіднішим шляхом забруднення вод. Отже, вміст нітратів збільшується у літньо-осінній періоди на всіх територіях, що пов'язано з паводком 3 водозборів. Збільшення вмісту нітратів восени пов'язано зі збільшенням розмірів змиву нітратів в період осінніх дощів.

Присутність нітрату амонію в концентраціях порядку 2 мг/л не викликає порушення біохімічних процесів у водоймі; підпорогова концентрація цієї речовини, яка не впливає на санітарний режим водойми, 10 мг/л. Щодо дії на людину - розрізняють первинну токсичність власне нітрат-йону; вторинну, пов'язану 3 утворенням нітрит-іонів, та третинну, зумовлену утворенням із нітритів та нітрозамінів. Смертельна доза нітратів для людини складає 8-15 г (Zapolskyi, 2005). Нормативне значення ГДК за вмістом нітратів становить 45 мг/дм (Zenin and Belousova, 1988).

Дані щодо вмісту досліджуваних показників відо- 
бражені у табл. 1. Встановлено, що на даній території дослідження відмічаються низькі концентрації нітритів протягом всього періоду дослідження. Окрім поодиноких випадків його зростання: восени (до $0,02 \mathrm{мг} /$ дм$^{3}$ ) та навесні (до 0,04 мг/дм ${ }^{3}$ ), що пояснюється збільшенням кількості опадів і відповідно зростанням поверхневого стоку з сільськогосподарських угідь. Незначні концентрації нітритів у грунтових

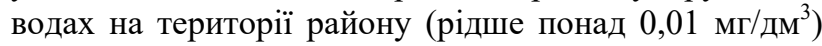
обумовлені їхньою крайньою нестійкістю. Вони окислюються, переходячи в найбільш стійкі неорганічні сполуки азоту - нітрати. Стійкість нітратних форм призводить до нагромадження їх у грунтових водах за рахунок інфільтрації грунтових розчинів, найбагатших цими сполуками, і ще більше в результаті господарської діяльності (внесення на поверхню грунту азотних мінеральних і органічних добрив) та забруднення середовища газоподібними, твердими і рідкими азотними сполуками (Zakon Ukrainy, 2002). У досліджуваних пробах води із нецентралізованих джерел даний показник не перевищує норми, окрім осені, коли він становить 52,35 мг/дм ${ }^{3}$. Значні підвищення концентрації нітратів восени пояснюються тим, що під час дощів у грунтові води потрапляли забруднювальні речовини, які стікали $з$ полів, на які вносили азотні добрива. Влітку підвищення можна пояснити внесенням добрив.

\section{Таблиця 1}

Стан якості водних ресурсів децентралізованого водопостачання за деякими хімічними показниками у різні пори року

\begin{tabular}{|c|c|c|c|c|}
\hline \multirow{2}{*}{ Назва села } & \multicolumn{4}{|c|}{ Пори року } \\
\hline & зима & весна & літо & осінь \\
\hline \multicolumn{5}{|c|}{$\begin{array}{l}\text { Нітрити, норма } \\
0,00 \mathrm{мг} / \text { дм }^{3}\end{array}$} \\
\hline Біще & 0,003 & 0,003 & 0,003 & 0,002 \\
\hline Жуків & 0,004 & 0,004 & 0,004 & 0,004 \\
\hline Баранівка & 0,004 & 0,004 & 0,004 & 0,003 \\
\hline \multicolumn{5}{|c|}{$\begin{array}{c}\text { Нітрати, норма } \\
50 \mathrm{~m} / \text { дм }^{3}\end{array}$} \\
\hline Біще & 50,78 & 60,41 & 77,2 & 104,7 \\
\hline Посухів & 96,65 & 58,59 & 137,9 & 181,6 \\
\hline Жуків & 39,46 & 25,5 & 39,87 & 52,35 \\
\hline Баранівка & 62,02 & 47,34 & 56,38 & 109,4 \\
\hline \multicolumn{5}{|c|}{$\begin{array}{c}\text { Хлориди, норма } \\
250 \text { мг/дм }{ }^{3}\end{array}$} \\
\hline Біще & 54 & 76,5 & 79,3 & 88 \\
\hline Жуків & 32 & 56,3 & 57,2 & 78,1 \\
\hline Баранівка & 48,3 & 68 & 42,9 & 84,7 \\
\hline Посухів & 58 & 33 & 65,9 & 90,2 \\
\hline \multicolumn{5}{|c|}{$\begin{array}{c}\text { Сульфати, норма } 250 \\
\text { мг/дм }{ }^{3}\end{array}$} \\
\hline Біще & 78,5 & 95,3 & 96,2 & 121,7 \\
\hline Жуків & 38,09 & 63,5 & 75 & 152,4 \\
\hline Баранівка & 36,1 & 60,32 & 40 & 80,3 \\
\hline Посухів & 65,08 & 44,44 & 79,49 & 112,45 \\
\hline
\end{tabular}

У середньому перевищення нормативів щодо вмісту нітратів у колодязній воді складало 1,1-1,6 раза. Щодо періоду досліджень, то природно, що в теплу пору року вміст нітратів у воді був значно вищим, ніж в холодний період. Крім того, на якість колодязної води впливає цілий ряд чинників, зокрема характер та гранулометричний склад грунту, дози та асортимент використовуваних органічних і мінеральних добрив, застосування пестицидів, характер складування побутових відходів, тип вбиральні (вигрібна яма), близькість до автошляхів, наявність індивідуальної чи колективної автостоянки тощо.

\section{Висновки}

У статті наведені дані щодо динаміки хімічних показників (водневий показник, хлориди, сульфати, твердість, нітрати, нітрити, азот амонійний) джерел питної води нецентралізованого водопостачання. Встановлено погіршення якості води у досліджених зразках навесні та восени. Улітку та взимку ситуація поліпшується. Згідно з ГДК - якість води відповідає нормі, однак флуктуаційні відхилення проаналізованих показників свідчать про зниження буферної ємкості та порушення регуляторних механізмів підтримання хімічного балансу в досліджених пробах води.

\section{References}

Derzhavni sanitarni normy ta pravyla (2010). «Hihiienichni vymohy do vody pytnoi, pryznachenoi dlia spozhyvannia liudynoiu» (DSanPiN 2.2.4-17110) http://zakon5.rada.gov.ua/laws/show/z0452-10 (in Ukrainian).

Himicheskij i bakteriologicheskij analiz (2004). Viddil derzhavnogo analitichnogo kontrolju ta monitoringu. 17.03.2004 (in Russian).

Hordejnk, T. (1996). Wyniki monitoringu jakosci zwyklych wod podziemnych w latach 1991-1995 (siec krajowa), PIOS, Bibl. Monit. srod. Warszawa.

Huang, J.-C., Lee, T.-Y., Kao S.-J., Hsu S.-C., Lin H.-J., \& Peng T.-R. (2012). Land use effect and hydrological control on nitrate yield in subtropical mountainous watersheds. Hydrology and Earth System Sciences. 16(3), 699-714 doi: 10.5194/hess16-699-2012.

Linnik, P.N. (1999). Heavy metals in the surface waters of Ukraine: content and migration ways. Hydrobiological Journal. 35(1), 22-41. doi: 10.1615/HydrobJ.v36.i3.20.

Mackey, K.R.M., Chien, C.-T., \& Paytan, A. (2014). Microbial and biogeochemical responses to projected future nitrate enrichment in the California upwelling system. Frontiers in Microbiology. 5. doi: 10.3389/ fmicb.2014.00632.

Michalczyk, Z. (1996). Zrodla Roztocza. Monografia hydrograficzna, Wyd. UMCS. Lublin.

Obukhov, I. (1988). Biogeochemistry of heavy metals in urban areas. Soil science. 5, 78-81.

Pennington, J.T., \& Chavez, F. (2000). Seasonal fluctuations of temperature, salinity, nitrate, chlorophyll, and primary production at station H3/M1 over 1989-1996 in Monterey Bay, CA. Deep Sea Research Part II: Topical Studies in Oceanography. 
47(5-6), 947-973. doi: 10.1016/S0967- http://consultant.parus.ua/?doc=019RM32609 (in 0645(99)00132-0. Ukrainian).

Rozkowski, J. (1996). Przeobrazenia skladu chemicznego wod krasowych poludniowej che_sci Wyzyny Krakowskiej (zlewnia Rudawy i Pradnika), Wyd. US; Kras i Speleologia, Numer specjalny 1.

Zakon Ukrainy (2002). «Pro pytnu vodu ta pytne vodopostachannia)

vid $\quad 10.01 .2002$

Zapolskyi,

A.K.

(2005).

Vodopostachannia, vodovidvedennia ta yakist vody: Pidruchnyk. K.: Vyshcha shkola (in Ukrainian).

Zenin, A.A., \& Belousova, N.V. (1988). Gidrohimicheskij slovar'. L.: Gidrometeoizdat (in Russian). 